\title{
DISTRIBUTION OF THREE NYMPHAEID MACROPHYTES (NYMPHAEA ALBA L., NUPHAR LUTEA (L.) SM. AND NYMPHOIDES PELTATA (GMEL.) O. KUNTZE) IN RELATION TO ALKALINITY AND UPTAKE OF INORGANIC CARBON
}

\section{A.J.M. SMITS, M.J.H. DE LYON ${ }^{1}$, G. VAN DER VELDE, P.L.M. STEENTJES and J.G.M. ROELOFS}

Laboratory of Aquatic Ecology, Catholic University of Nijmegen, Toernooiveld, 6525 ED Nijmegen (The Netherlands)

(Accepted for publication 17 May 1988)

\section{ABSTRACT}

Smits, A.J.M., de Lyon, M.J.H., van der Velde, G., Steentjes, P.L.M. and Roelofs, J.G.M., 1988. Distribution of three nymphaeid macrophytes (Nymphaea alba L., Nuphar lutea (L.) Sm. and Nymphoides peltata (Gmel.) 0 . Kuntze) in relation to alkalinity and uptake of inorganic carbon. Aquat. Bot., 32: 45-62.

The presence/absence data of Nymphaea alba L., Nuphar lutea (L.) Sm. and Nymphoides peltata (Gmel.) O. Kuntze in 588 water bodies throughout The Netherlands were converted into logistic response curves with respect to alkalinity. For Nuphar lutea and Nymphoides peltata maximum probability of occurrence was found at 2.86 and $3.76 \mathrm{meq}^{-1}$, respectively. Nymphaea alba has a broad ecological amplitude with respect to alkalinity in comparison with Nuphar lutea and Nymphoides peltata. Within the $95 \%$ confidence interval no optimum for Nymphaea could be determined.

Uptake capacity for dissolved inorganic carbon (DIC) was examined using the $\mathrm{pH}$-drift technique. In a 1-mM $\mathrm{NaHCO}_{3}$ solution the DIC-extracting capacities of Nymphaea alba, Nuphar lutea and Nymphoides peltata were compared with those of the $\mathrm{HCO}_{3}^{-}$-using macrophyte Potamogeton gramineus $\mathrm{L}$. Unlike the situation for Potamogeton gramineus, no uptake of $\mathrm{HCO}_{3}^{-}$ could be registered by the floating and submerged laminae of the 3 nymphaeid species studied.

A very limited uptake of $\mathrm{HCO}_{3}^{-}$was measured when Nymphaea alba, Nuphar lutea and Nymphoides peltata seedlings were cultivated in solutions with a high bicarbonate concentration. Under natural conditions uptake of $\mathrm{HCO}_{3}^{-}$can be neglected.

\section{INTRODUCTION}

Several biotic and abiotic factors determine the occurrence and abundance of aquatic macrophytes (Sculthorpe, 1967; Hutchinson, 1975). Spence (1967)

\footnotetext{
${ }^{1}$ Present address: Computing Centre, Catholic University of Nijmegen, Geert Grooteplein 241, 6525 GA Nijmegen, The Netherlands.
} 
has even suggested that macrophyte establishment and development are mainly based on water chemistry, provided that space is available and propagules of the species are present at a particular locality. It has been recognized however, that the sediment characteristics also influence the species composition of aquatic macrophyte communities (Barko and Smart, 1980, 1983).

A causal relation between the available carbon source and the distribution of aquatic macrophytes has already been reported by Steemann-Nielsen (1944). All submerged aquatic macrophytes can use dissolved $\mathrm{CO}_{2}$ for photosynthesis, but additional $\mathrm{HCO}_{3}^{-}$assimilation is confined to certain algae and a limited number of aquatic angiosperms (Raven, 1970; Maberly and Spence, 1983; Spence and Maberly, 1985). Among the aquatic bryophytes examined so far (Bain and Proctor, 1980) a limited utilization of bicarbonate was ascertained only for Fontinalis antipyretica Hedw. (Peñuelas, 1985).

In view of this difference in C-extractive capacity, it is not surprising that a number of investigations have revealed a significant correlation between the alkalinity of a water body and the occurrence of certain species (Spence, 1967; Adams et al., 1978; Wiegleb, 1978; Pip, 1979; Hellquist, 1980; Kadono, 1982a,b).

Nymphaeid water plants do not depend entirely on the water phase for their carbon source. The upper surfaces of the floating leaves contain functional stomata, allowing $\mathrm{CO}_{2}$ from the atmosphere to be fixed by photosynthesis (Hutchinson, 1975). Little is known about the relative contributions of air and water to the photosynthesis of heterophyllous plants (cf. Spence and Maberly, 1985 ). However, Filbin (1980) found that the aqueous phase can be a considerable source of inorganic carbon for Lemna minor L. and for the floating leaves of two nymphaeacean species, although its contribution varies with the age of the leaves. Carbon assimilation of nymphaeid macrophytes is restricted to the green submerged parts of the plant during some phases of the life cycle. Seedlings and young plants of Nymphaea alba L. and Nuphar lutea (L.) Sm. produce only submerged leaves. Consequently, the biomass production of these plants during the establishing phase is completely dependent on the availability of dissolved inorganic carbon (DIC). After germination under water Nymphoides peltata (Gmel.) O. Kuntze develops two lanceolate cotyledons which are succeeded by some thin, circular leaves which resemble the submerged leaves of Nymphaea alba and Nuphar lutea. In contrast to the underwater leaves of Nymphaea alba and Nuphar lutea, the inundated leaves of the Nymphoides peltata seedlings can develop into floating leaves after they have reached the water surface.

During winter and early spring, only submerged leaves are present on the rhizome of the Nuphar lutea plant. In streams, Nuphar lutea develops only submerged leaves. Nymphaea alba produces less underwater leaves compared with Nuphar lutea and the production of these leaves ceases when the floating leaves are developing.

In view of the substantial parts of the life cycle in which the carbon source 
for photosynthesis is restricted to DIC, it is of importance to study the distribution of these macrophytes in relation to alkalinity and their uptake capacity of DIC. In the present study, the occurrence of the three nymphaeids $\mathrm{Nym}$ phaea alba, Nuphar lutea and Nymphoides peltata in a large number of water bodies is related to water alkalinity, and the DIC-extractive capacity of these macrophytes is studied using the $\mathrm{pH}$-drift technique (Allen and Spence, 1981).

\section{MATERIAL AND METHODS}

\section{Field studies}

During the period 1978-1984, 588 aquatic habitats were surveyed. Among them were ditches, ponds, moorland pools, oxbow lakes and rivers throughout The Netherlands. Each water body was visited 2-4 times a year, during winter and summer. The presence or absence of nymphaeids was registered and $\mathrm{pH}$ and alkalinity of the surface water measured. Alkalinity was determined immediately after collection of the water sample by titration with $0.1-\mathrm{M} \mathrm{HCl}$ down to $\mathrm{pH}$ 4.2. The $\mathrm{pH}$ was measured with a type EA-152 (Metrohm) combined electrode, connected to a Metrohm Herisau E- $488 \mathrm{pH} / \mathrm{mV}$ meter. The data of occurrence of Nymphaea alba, Nuphar lutea and Nymphoides peltata in relation to water alkalinity were analysed with the Gaussian logistic regression method (GLR) (Austin, 1980; Austin et al., 1984), according to the regression analysis available in the standard statistical package (PROC LOGIST; S.A.S., 1986).

\section{Experiments}

\section{Determination of inorganic carbon uptake; $p H$-drift experiments}

Carbon uptake by plant material was measured using a procedure which was slightly modified from the one described by Allen and Spence (1981). The measurement involved continuous registration of the $\mathrm{pH}$ in a DIC solution with photosynthesising plants. All experiments were conducted at $16^{\circ} \mathrm{C}$ $\left( \pm 0.5^{\circ} \mathrm{C}\right)$ in a temperature-controlled chamber. During the experiments, light was provided by a $150-\mathrm{W}$ halogen lamp at an intensity of $550 \mu$ Einstein $\mathrm{m}^{-2}$ $\mathrm{s}^{-1}$. Freshly-collected plant material or cultivated seedlings were used. The $\mathrm{pH}$ measurements were discontinued when no increase in $\mathrm{pH}$ had occurred for at least $1 \mathrm{~h}$. Carbon uptake was calculated from the change in $\mathrm{pH}$ with time resulting from carbon assimilation. The $\mathrm{pH}$ was measured by means of two combined electrodes (Metrohm EA 152) and recorded simultaneously on a chart recorder (TOA EPR 200A). The electrodes were calibrated against buffers of $\mathrm{pH} 7.0$ and 8.5 at $16^{\circ} \mathrm{C}$. Experiments in which the two electrodes gave nonidentical $\mathrm{pH}$ values during the measurements were rejected. The relative proportions of $\mathrm{CO}_{2}, \mathrm{HCO}_{3}^{-}$and $\mathrm{CO}_{3}^{2-}$ were calculated from $\mathrm{pH}$, temperature and 
ionic strength according to Stumm and Morgan (1970). On occasions the oxygen produced at the end of the experiment was determined by Winkler titration (Drew and Robertson, 1974).

\section{Uptake of inorganic carbon in a 1-mM $\mathrm{NaHCO}_{3}$ solution}

The carbon-uptake capacity of floating leaves of Nymphaea alba, Nuphar lutea and Nymphoides peltata seedlings in a 1- $\mathrm{mM} \mathrm{NaHCO}$ solution was determined. The submerged leaves of Nymphaea alba and Nuphar lutea were also tested. The carbon-extracting capacity of Potamogeton gramineus L., which was expected to use $\mathrm{HCO}_{3}^{-}$for photosynthesis, was measured in order to compare the obtained results.

Plant material was obtained from a cultivated stock. The plants were grown on clay in large glass aquaria or polyethylene tanks filled with tap water of moderate alkalinity (c. 1.5 meq $^{-1}$ ). Light was provided by a metal halide lamp (Philips HP; $400 \mathrm{~W}$ ) at $200 \mu$ Einstein $\mathrm{m}^{-2} \mathrm{~s}^{-1}$ with a daily photoperiod of 18 h.

Uptake of inorganic carbon by seedlings cultivated at varying alkalinity

As $\mathrm{HCO}_{3}^{-}$uptake is dependent on the available concentration (Allen and Spence, 1981), seedlings of Nymphaea alba, Nuphar lutea and Nymphoides peltata were cultivated in media at varying alkalinity (i.e. varying $\mathrm{HCO}_{3}^{-}$concentration). The seedlings were grown in a mixture of sand and clay in large glass containers $(40 \mathrm{l})$. The aquaria were filled with a culture medium consisting of salts added to twice-demineralized water (see Table 1). The concentration of each nutrient was within the range of the nutrient concentrations found in water bodies dominated by nymphaeid water plants (van der Velde et al., 1986 ). By adding different amounts of $\mathrm{NaHCO}_{3}$ the alkalinity of the medium

\section{TABLE 1}

Chemical composition of the cultivation medium to which different amounts of $\mathrm{NaHCO}_{3}$ were added

\begin{tabular}{lcll}
\hline $\begin{array}{l}\text { Major } \\
\text { components }\end{array}$ & $(\mu \mathrm{M})$ & Minor components & $(\mu \mathrm{M})$ \\
\hline $\mathrm{Na}_{2} \mathrm{SO}_{4}$ & 570 & $\mathrm{FeCl}_{3}$ & 2.0 \\
$\mathrm{~K}_{2} \mathrm{HPO}_{4}$ & 1.5 & $\mathrm{CuSO}_{4}$ & 0.0005 \\
$\mathrm{CaCl}_{2}$ & 820 & $\mathrm{MnCl}_{2}$ & 0.4 \\
$\mathrm{KCl}_{\mathrm{NH}} \mathrm{NO}_{3}$ & 130 & $\mathrm{ZnSO}_{4}$ & 0.04 \\
$\mathrm{MgCl}_{2}$ & 30 & $\mathrm{Co}\left(\mathrm{NO}_{3}\right)_{2}$ & 0.01 \\
& 200 & $\mathrm{H}_{3} \mathrm{BO}_{3}$ & 0.04 \\
& & $\mathrm{EDTA}$ & 0.2 \\
& & $\left(\mathrm{NH}_{4}\right)_{6} \mathrm{Mo}_{7} \mathrm{O}_{24}$ & 0.001 \\
& & $\mathrm{NH}_{4} \mathrm{VO}_{3}$ & 0.02 \\
\hline
\end{tabular}


was varied. The culture medium was regularly replaced and filamentous algae were removed by hand, in order to prevent large fluctuations in $\mathrm{pH}$ and DIC concentrations. The seedlings were cultivated at alkalinities of approximately $0.6,1.0,2.5$ and 5.0 meq $^{-1}$ during $4-16$ weeks. Subsequently, the C-extractive capacity of these seedlings was determined. Prior to the experiments the alkalinity of the cultivation medium was accurately determined and the carbon uptake of the seedlings was measured in a $\mathrm{NaHCO}_{3}$ solution with a corresponding alkalinity.

\section{Photosynthetic activity in an oxygen-depleted solution}

On occasions, when a pH-drift experiment was terminated, dissolved $\mathrm{O}_{2}$ was determined. After incubations in media of high alkalinity $\left(>1.0 \mathrm{meq}^{-1}\right)$ in particular, an oversaturation of dissolved $\mathrm{O}_{2}$ was measured (155-240\% air saturation; data not shown). It is not inconceivable that a high $\mathrm{O}_{2}$ concentration could have a negative effect on the uptake of $\mathrm{HCO}_{3}^{-}$. Therefore, in an oxygendepleted solution the photosynthetic activity of the nymphaeid seedlings and Potamogeton gramineus was measured. The plants were allowed to photosynthesize in a solution containing only $\mathrm{HCO}_{3}^{-}$as DIC (a), and in a solution containing both $\mathrm{CO}_{2}$ and $\mathrm{HCO}_{3}^{-}$(b).



Fig. 1. Frequency distributions of the sampled waters $(n=588)$ with respect to alkalinity. The bars show the number of water bodies in each alkalinity class. Each class (except the extremes) is defined by $\left(x-0.5\right.$ meq $\left.^{-1}\right)<x \leq\left(x+0.5\right.$ meq $\left.^{-1}\right)$. Mineral acidity is equivalent to negative alkalinity. 
(a) The $\mathrm{pH}$ of a $2-\mathrm{mM} \mathrm{NaHCO}_{3}$ solution was adjusted to $\mathrm{pH} 8.3$ with $0.1-\mathrm{N}$ $\mathrm{NaOH}$ solution so that $\mathrm{HCO}_{3}^{-}$was the only DIC source available. The bicarbonate solution was bubbled through with nitrogen gas in order to reduce the concentration of dissolved oxygen to approximately $30 \mu \mathrm{M}$. Some leaves of each species (about 3-g fresh weight) were rinsed in distilled water and subsequently incubated in closed serum bottles $(130 \mathrm{ml})$ containing the hypoxic 2-mM NaHCO 3 solution.

(b) The laminae of Nymphaea alba, Nuphar lutea, Nymphoides peltata and $P$. gramineus were also incubated in the hypoxic $2-\mathrm{mM} \mathrm{HCO}_{3}^{-}$solution. Prior to the incubation, however, acid $(0.1-\mathrm{N} \mathrm{HCl})$ was injected through the rubber stopper of the serum bottles in order to obtain a solution containing $0.5-\mathrm{mM}$ $\mathrm{CO}_{2}$ and $1.5-\mathrm{mM} \mathrm{HCO}_{3}^{-}$. Photosynthetic activity was determined by measuring the produced oxygen. Dissolved oxygen was determined according to Drew and Robertson (1974). The seedlings of the nymphaeids and $P$. gramineus used in this experiment were cultivated in a culture medium (see Table 1) containing 3-mM NaHCO 3 . Prior to the experiments, plant material was carefully cleaned of debris and rinsed in distilled water. Only submerged leaves were used. The measurements were conducted at $20^{\circ} \mathrm{C}$ and at a light intensity of $250 \mu$ Einstein $\mathrm{m}^{-2} \mathrm{~s}^{-1}$. In all treatments the incubations were terminated before the $\mathrm{O}_{2}$ content in the serum bottles, equalled the air-saturated $\mathrm{O}_{2}$ concentration.

\section{RESULTS}

\section{Field studies}

Figure 1 shows the frequency distribution of the sampled water bodies with respect to alkalinity classes. It can be noted that most of the sampled water bodies had a low to moderate alkalinity $\left(0.5-15 \mathrm{meq}^{-1}\right)$, which resulted in a positively skewed sample distribution of alkalinity. As a consequence, estimation of the indicator values and ecological amplitudes by weighted averaging and calculating medians, respectively, would be unreliable. Therefore, the

Fig. 2. The occurrence of Nymphaea alba, Nuphar lutea and Nymphoides peltata along the alkalinity gradient. Mineral acidity is equivalent to negative alkalinity. Water bodies in which the plant species concerned were found are marked with an open dot on the $P=1$ level (ordinate). $p_{\max }$, maximal probability of occurrence; $u$, alkalinity value of a water body with the highest probability of occurrence; $t$, ecological amplitude with regard to alkalinity. The optimum of the curve $(u)$ is the alkalinity value of a water body with the highest probability of occurrence $\left(p_{\max }\right)$ of a species. The tolerance $(t)$ is a measure of peak width and provides information about the preferred range of water alkalinity (ecological amplitude). The standard errors of the estimated parameters are presented in Table 2. For a mathematical definition of the individual parameters the reader is referred to ter Braak and Looman (1986). 

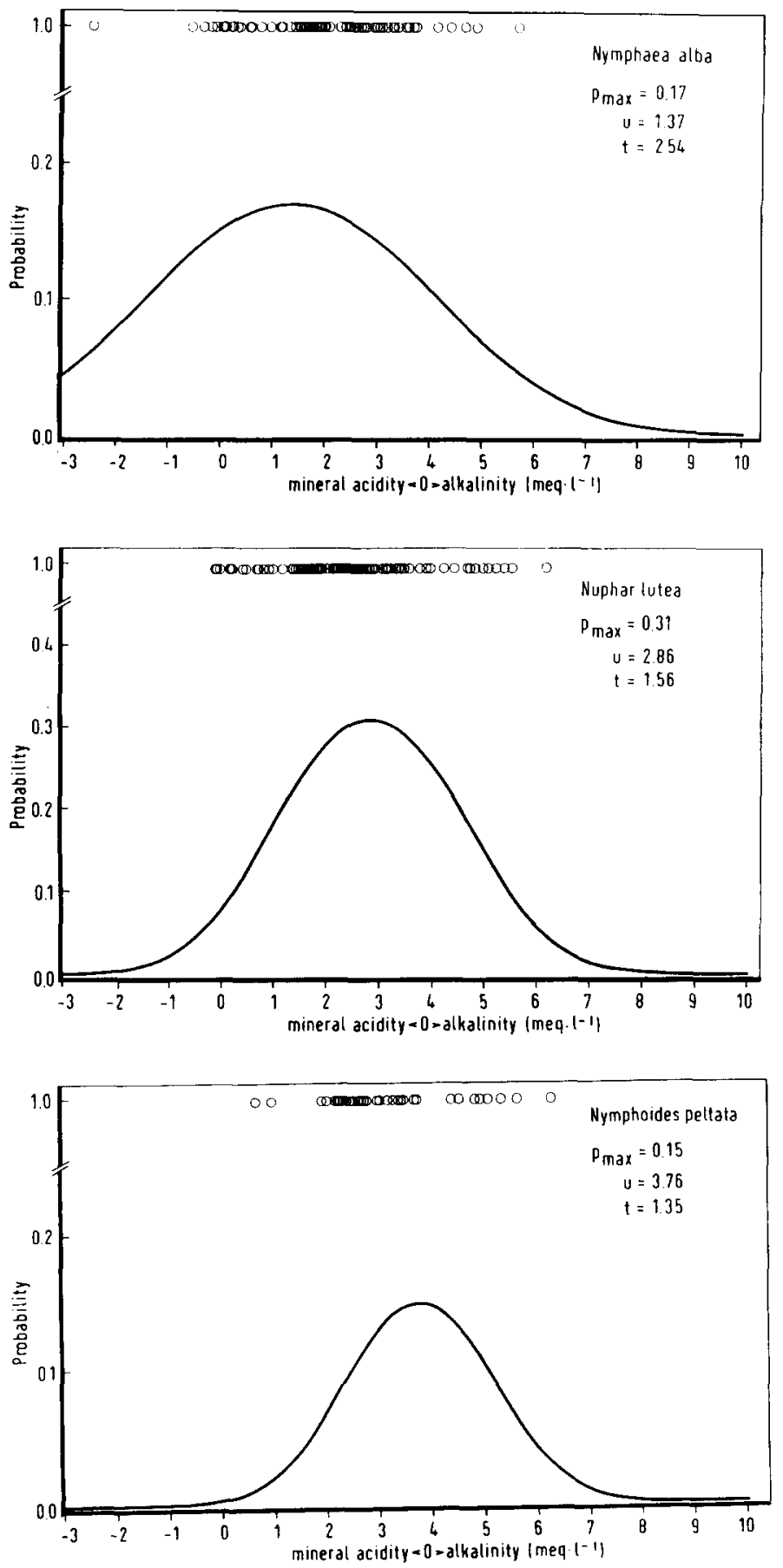
TABLE 2

The estimates for maximum probability $\left(p_{\max }\right)$, optimum $(u)$ and tolerance $(t)$ of the logistic response curves shown in Fig 2

\begin{tabular}{lcccccccrrr}
\hline & $p_{\max }$ & s.e. & $t$ & s.e. & $u$ & s.e. & $\begin{array}{l}\text { conf. } \\
\text { intv. }\end{array}$ & lower & upper \\
& & & & & & & & \\
\hline Nuphar lutea & 0.31 & 0.03 & 1.56 & 0.17 & 2.86 & 0.20 & $95 \%$ & 2.45 & 3.43 \\
Nymphaea alba & 0.17 & 0.02 & 2.54 & 0.69 & 1.37 & 0.74 & $90 \%$ & -8.00 & 2.25 \\
Nymphoides peltata & 0.15 & 0.03 & 1.35 & 0.20 & 3.76 & 0.30 & $95 \%$ & 3.21 & 5.03 \\
\hline
\end{tabular}

s.e.: standard error of the estimate.

The upper and lower limits of the $95 \%$ or $90 \%$ confidence interval (conf. intv.) of $u$ are given. Standard errors of the estimates were computed according to ter Braak and Looman (1986) and the Appendix.

Gaussian logistic regression (GLR) procedure was used to estimate species optima and ecological amplitudes from presence/absence data. These presence/absence data, modelled with GLR, result in an unimodal occurrenceprobability curve. The Gaussian logit response curves for Nymphaea alba, $\mathrm{Nu}$ phar lutea and Nymphoides peltata are depicted in Fig. 2.

The relatively high values of " $p_{\max }$ " and " $t$ " of the response curve of Nuphar lutea indicate that this species is the most common in the waters sampled $\left(p_{\max }=0.31 ; t=1.56\right)$, followed by Nymphaea alba $\left(p_{\max }=0.17 ; t=2.54\right)$ and Nymphoides peltata $\left(p_{\max }=0.15 ; t=1.35\right)$.

Nymphoides peltata is restricted to waters with a relatively high alkalinity ( $u=3.76 \mathrm{meq}^{-1}$ ) while Nuphar lutea shows highest frequency in waters of a slightly lower alkalinity $\left(u=2.86 \mathrm{meq}^{-1}\right)$. The alkalinity range of waters which are likely to harbour Nuphar lutea is greater than that of waters with Nymphoides peltata $(t=2.54,1.56$, respectively). Nymphaea alba has a broad ecological amplitude. The optimum $(u)$ could not be estimated reliably. No $95 \%$ confidence interval could be calculated. The $90 \%$ confidence interval given in Table 2 shows that the species favours low alkalinities. Moreover, it may be noted that unlike Nymphoides peltata, Nymphaea alba and Nuphar lutea occur in acid waters in which dissolved inorganic carbon is available only as $\mathrm{CO}_{2}$.

\section{Experiments}

Uptake of inorganic carbon in a 1-mM $\mathrm{NaHCO}_{3}$ solution

Carbon-uptake rates calculated from $\mathrm{pH}$-drift experiments in a solution of 1 - $\mathrm{mM} \mathrm{NaHCO}_{3}$ are shown in Fig. 3. The DIC uptake of $P$. gramineus can be described by a two-phased curve, which is obtained when both $\mathrm{CO}_{2}$ and $\mathrm{HCO}_{3}^{-}$are removed from the solution (Allen and Spence, 1981). It has been suggested that this $\mathrm{C}$-uptake curve is composed of two components. The linear 

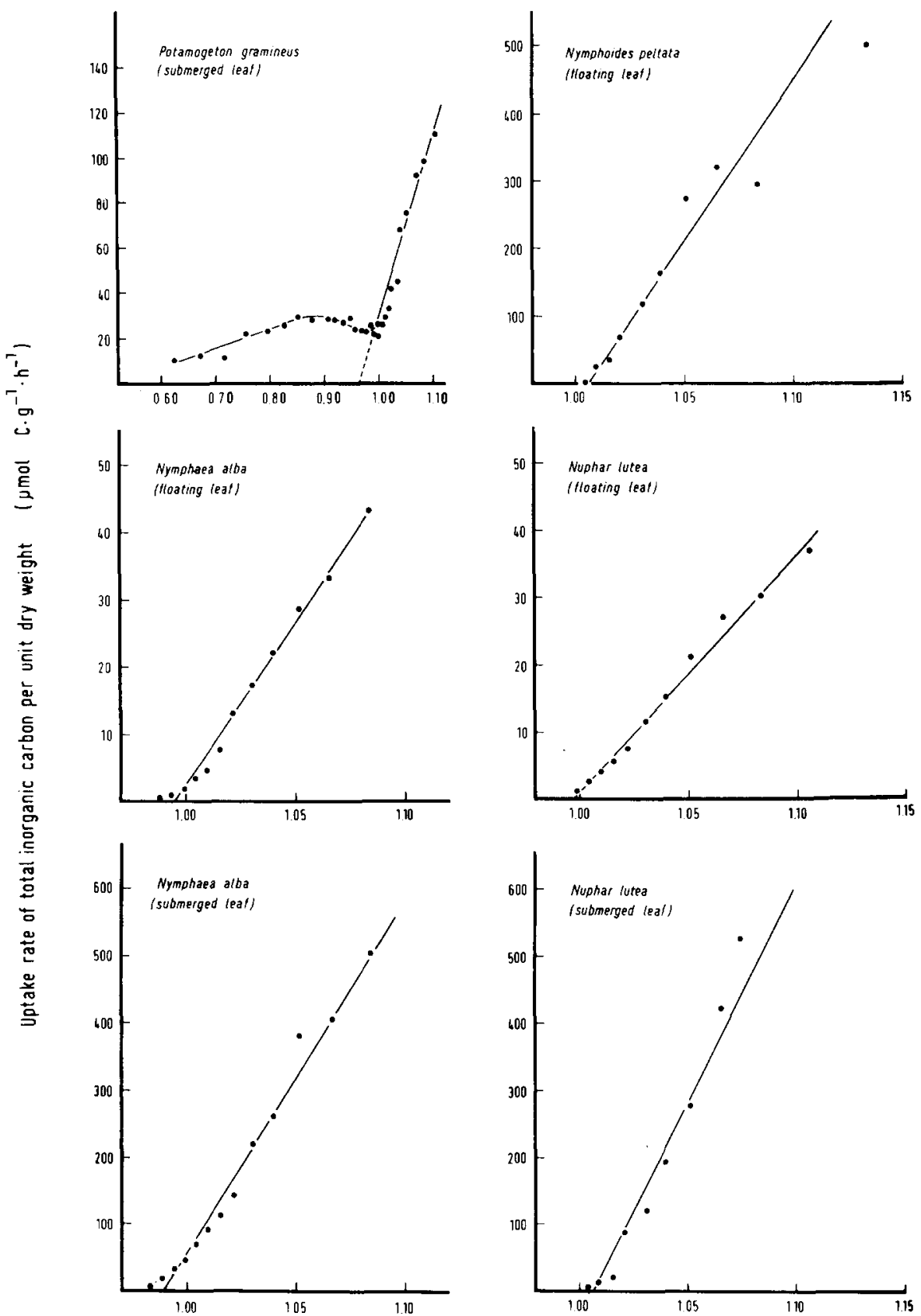

Total inorganic carbon concentration $\left[C_{T}\right]\left(m m o l \cdot l^{-1}\right)$

Fig. 3. Rate of carbon uptake plotted against the total inorganic carbon concentration $\left(\mathrm{C}_{\mathrm{T}}\right)$ in a closed constant alkalinity system. A solution of $1-\mathrm{mM} \mathrm{NaHCO}{ }_{3}$ was used in all experiments. 
TABLE 3

Data obtained from pH-drift experiments using an 1-mM NaHCO${ }_{3}$ solution

\begin{tabular}{llll}
\hline & $\begin{array}{l}\text { Final } \\
\mathrm{pH}\end{array}$ & $\mathrm{C}_{\mathrm{T}} / \mathrm{Alk}$ & $\begin{array}{l}\mathrm{CO}_{2} \\
\text { compensation }\end{array}$ \\
$\begin{array}{l}\text { point } \\
(\mu \mathrm{M})\end{array}$ \\
\hline $\begin{array}{l}\text { Potamogeton gramineus } \\
\begin{array}{c}\text { Nymphoides peltata } \\
\text { (floating leaf) }\end{array}\end{array}$ & 10.30 & 0.51 & 4.1 \\
$\begin{array}{c}\text { Nymphaea alba } \\
\text { (floating leaf) }\end{array}$ & 8.25 & 1.00 & 13.5 \\
$\begin{array}{c}\text { Nuphar lutea } \\
\text { (floating leaf) }\end{array}$ & 8.45 & 0.99 & 8.4 \\
$\begin{array}{c}\text { Nymphaea alba } \\
\text { (submerged leaf) }\end{array}$ & 8.45 & 0.99 & 8.4 \\
Nuphar lutea \\
(submerged leaf)
\end{tabular}

${ }^{1} \mathrm{CO}_{2}$ compensation points calculated according to Allen and Spence (1981).

\section{TABLE 4}

Data derived from pH-drift experiments with Nymphoides, Nymphaea and Nuphar seedlings

\begin{tabular}{llllll}
\hline Species & $\begin{array}{l}\left(\mathrm{HCO}_{3}^{-}\right)^{1} \\
(\mathrm{mM})\end{array}$ & $\begin{array}{l}\left(\mathrm{HCO}_{3}^{-}\right)^{2} \\
(\mathrm{mM})\end{array}$ & $\begin{array}{l}\text { Final } \\
\mathrm{pH}\end{array}$ & $\mathrm{C}_{\mathrm{T}} / \mathrm{Alk}$ & $\begin{array}{l}\mathrm{CO}_{2} \\
\text { compensation } \\
\text { point } \\
(\mu \mathrm{M})\end{array}$ \\
\hline Nymphoides peltata & 0.6 & 0.62 & 8.40 & 0.98 & 6.5 \\
& 2.5 & 2.44 & 9.00 & 0.96 & 18 \\
& 5.0 & 4.84 & 9.00 & 0.96 & 18 \\
Nymphaea alba & 0.6 & 0.58 & 8.50 & 1.04 & 5 \\
& 2.5 & 2.42 & 8.90 & 0.98 & 13 \\
& 5.0 & 4.80 & 8.80 & 0.98 & 29 \\
Nuphar lutea & & & & & \\
& 06 & 0.59 & 8.50 & 1.02 & 5 \\
& 2.5 & 2.49 & 9.10 & 0.93 & 14 \\
& 5.0 & 4.88 & 8.90 & 0.96 & 28 \\
\hline
\end{tabular}

${ }^{1}$ The approximate bicarbonate concentration in which the seedlings were cultivated. During the culture the $\mathrm{HCO}_{3}^{-}$concentration fluctuated about $0.5 \mathrm{meq}^{-1}$.

${ }^{2}$ The accurate bicarbonate concentration at the start of an experiment.

${ }^{\mathrm{c}} \mathrm{CO}_{2}$ compensation points calculated according to Allen and Spence (1981). 


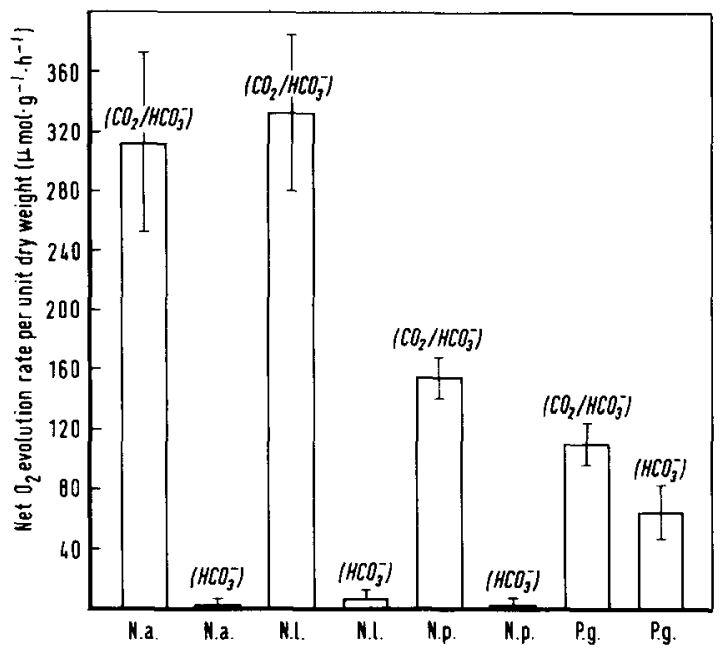

Fig. 4. Oxygen production of Nymphaea alba (N.a.), Nuphar lutea (N.1.), Nymphoides peltata (N.p.) and Potamogeton gramineus (P.g.) in a hypoxic solution under various DIC conditions. Prior to the experiments oxygen was stripped from the incubation medium using nitrogen gas, after which $\mathrm{NaHCO}_{3}$ was added. In all experiments $\mathrm{C}_{\mathrm{T}}$ was $2 \mathrm{mM}$, but in half of the incubations $\mathrm{C}_{\mathrm{T}}$ consisted of $0.5 \mathrm{mM} \mathrm{CO}_{2}+1.5 \mathrm{mM} \mathrm{HCO}_{3}^{-}\left(\mathrm{CO}_{2} / \mathrm{HCO}_{3}^{-}\right)$, while in the other half DIC was present exclusively as $\mathrm{HCO}_{3}^{-}\left(\mathrm{HCO}_{3}^{-}\right)$. DIC composition was achieved by adding appropriate amounts of 0.1-N HCl. Each treatment was conducted in triplicate.

part of the curve represents $\mathrm{CO}_{2}$ uptake, while the remaining section is the result of $\mathrm{HCO}_{3}^{-}$uptake. Extrapolation of the linear part of the curve would yield the total DIC $\left(\mathrm{C}_{\mathrm{T}}\right)$ concentration at which net uptake of $\mathrm{CO}_{2}$ no longer occurs. The $\mathrm{CO}_{2}$ concentration at this point can be calculated and is assumed to be the $\mathrm{CO}_{2}$ compensation point. Extrapolation of the $\mathrm{HCO}_{3}^{-}$-uptake curve yields the $\mathrm{HCO}_{3}^{-}$compensation point under the experimental conditions.

The ratio of DIC to alkalinity $\left(\mathrm{C}_{\mathrm{T}} / \mathrm{Alk}\right)$ found in the solution after the plant has failed to continue the uptake of inorganic carbon is a measure of its $\mathrm{C}$ extracting capacity (Maberly and Spence, 1983). It can be deduced that at a $\mathrm{C}_{\mathrm{T}} / \mathrm{Alk}$ ratio of approximately $1.0, \mathrm{CO}_{2}$ is the main form of DIC removed from the solution. At lower $\mathrm{C}_{\mathrm{T}}$ /Alk values $\mathrm{HCO}_{3}^{-}$is used for photosynthesis as well.

In Tables 3 and 4 the results of the conducted $\mathrm{pH}$-drift experiments are shown. In a $1-\mathrm{mM} \mathrm{NaHCO}{ }_{3}$ solution $P$. gramineus achieved a $\mathrm{C}_{\mathrm{T}} /$ Alk of 0.51 indicating that $\mathrm{HCO}_{3}^{-}$can be an important source of inorganic carbon. In view of the uptake rates for $\mathrm{CO}_{2}$ and $\mathrm{HCO}_{3}^{-}$, respectively, it is evident that affinity towards $\mathrm{CO}_{2}$ is considerably higher. Only linear uptake curves are obtained in $\mathrm{pH}$-drift experiments with leaves of Nymphoides peltata seedlings and with both floating and submerged leaves of Nuphar lutea and Nymphaea alba, which reflects the very poor $\mathrm{HCO}_{3}^{-}$-extractive capacity of these macrophytes in a 1$\mathrm{mM} \mathrm{HCO}--$ solution. Compared with the floating leaves of Nymphaea alba and Nuphar lutea the C-uptake rates of the submerged leaves of Nuphar lutea, 
Nymphaea alba and Nymphoides peltata seedlings are markedly higher. This difference is most probably due to a high diffusion resistance as a result of the thick cuticle of the floating leaves, which under natural conditions prevents desiccation. Moreover, a fast exchange between dissolved carbon and the submerged laminae is easier than it is for the relatively thick floating leaves.

$\mathrm{pH}$-drift experiments conducted in solutions of high alkalinity gave lower $\mathrm{C}_{\mathrm{T}}$ /Alk ratios than measurements in solutions with low alkalinity (see Tables 3 and 4). The $\mathrm{C}_{\mathrm{T}} /$ Alk ratios are, however, not much lower than 1.0, indicating a very limited $\mathrm{HCO}_{3}^{-}$uptake. The increased $\mathrm{CO}_{2}$ compensation points determined at high alkalinities were probably caused by the increased photorespiration.

Uptake of inorganic carbon by seedlings cultivated at various alkalinities

Photosynthesis of Nymphaea alba, Nuphar lutea, Nymphoides peltata seedlings and $P$. gramineus in an oxygen-depleted medium under different DIC conditions is shown in Fig. 4. Only P. gramineus was able to produce $\mathrm{O}_{2}$ in a solution in which DIC consisted solely of $\mathrm{HCO}_{3}^{-}$. From the negligible photosynthetic activity of Nymphaea alba, Nuphar lutea and Nymphoides peltata in the ' $\mathrm{HCO}_{3}^{-}$-incubation experiment', as opposed to the considerable $\mathrm{O}_{2}$ production in the ' $\mathrm{CO}_{2} / \mathrm{HCO}_{3}^{-}$-incubation experiment', it can be concluded that the accumulated $\mathrm{O}_{2}$ in the $\mathrm{pH}$-drift experiments did not mask a limited $\mathrm{HCO}_{3}^{-}$uptake by these macrophytes.

\section{DISCUSSION}

According to Stumm and Morgan (1981) the most relevant non-carbonate bases that occur in fresh waters are the silicates $\left(10^{-4}-10^{-3} \mathrm{M}\right)$, implicating that, generally, measurements of water alkalinity provide a reasonable estimation of dissolved $\mathrm{HCO}_{3}^{-}$and $\mathrm{CO}_{3}^{2-}$.

In view of the alkalinity value with the highest frequency of occurrence and the small ecological amplitude of Nymphoides peltata with respect to alkalinity, it can be concluded that the habitat of this nymphaeid macrophyte is restricted to well-buffered waters.

After a survey of 17 selected surface waters, representing most of the aquatic macrophyte communities in Eastern Central Europe, Pietsch (1972) also classified Nymphoides peltata as a species restricted to water bodies with a high calcium-bicarbonate content.

Wiegleb (1978), who investigated the hydrochemical factors and the macrophyte vegetation of 79 lakes and ponds in Germany (F.R.G.), regarded Nymphoides peltata as a characteristic species of waters with an alkalinity higher than 2 meq $\mathrm{l}^{-1}$, which is in agreement with our results.

Like Nymphoides peltata, Nuphar lutea occurs mainly in alkaline waters, but its optimum alkalinity of occurrence is lower and its ecological amplitude, with regard to alkalinity, is larger. Hence, Nuphar lutea can be found in aquatic ecosystems with a low water alkalinity or even in acid waters. 
Iversen (1929) presented some records of the occurrence of Nuphar lutea in "acidotrophic" waters in Great Britain. The $\mathrm{pH}$ of these waters, however, was never lower than 6. According to Heslop-Harrison (1955a,b), Nymphaea alba occurs more frequently in weakly acid and nutrient-poor waters than Nuphar lutea. In contrast to the above mentioned authors, the occurrence of Nymphaea alba and Nuphar lutea in water bodies with a mineral acidity was recorded. In none of the sampled acid waters was Nymphoides peltata found.

The increase in acid precipitation over the last decades has led to the acidification of a great number of poorly-buffered waters in The Netherlands in which Nymphaea alba, and to a lesser extent, Nuphar lutea were usually found (Arts, 1987). Nymphaea alba and Nuphar lutea are still present in these acidified waters, in contrast to some characteristic species of soft waters. This development may have caused a shift of the occurrence range towards the acid water bodies.

In acid waters, submerged macrophytes are completely dependent on $\mathrm{CO}_{2}$ in the water column or in the sediment. The floating leaves of Nymphaea alba and Nuphar lutea, however, have access to atmospheric $\mathrm{CO}_{2}$. An additional source of inorganic carbon may be supplied by respiratory $\mathrm{CO}_{2}$. Dacey $(1980$, 1981 ) and Dacey and Klug (1982) have described an internal ventilation system which enhances oxygen transport to the rhizomes and roots of Nuphar lutea. Simultaneously, a more rapid movement of respiratory $\mathrm{CO}_{2}$ to the leaves is achieved, where it can be assimilated. This pressurized gas transport has also been found in Nelumbo nucifera Gaertn. (Merget, 1874; Ohno, 1910) and Nymphoides peltata (Grosse and Mevi-Schütz, 1987). It appears to be a general phenomenon in aquatic plants with floating or emergent leaves.

The production of floating leaves and the successful vegetative propagation of nymphaeids may, at least partly, explain the survival of Nymphaea alba and Nuphar lutea in acid water bodies. However, little is known about the germination and seedling development of these nymphaeids. Their generative reproduction in acid moorland pools is currently under investigation.

The DIC-uptake capacity of the floating leaves is not essential for demonstrating a possible relation between the distribution of Nymphaea alba, $\mathrm{Nu}$ phar lutea and Nymphoides peltata and the quantity and composition of DIC. As pointed out, the photosynthesis of the full-grown nymphaeid has become largely independent of DIC. Juvenile nymphaeids do not possess floating leaves, and thus have no access to atmospheric $\mathrm{CO}_{2}$. In addition, there is no enhanced ventilation of the internal atmosphere which would allow an efficient refixation of respiratory $\mathrm{CO}_{2}$ originating in the roots. Therefore, unlike the fullgrown macrophytes, photosynthesis of Nymphaea alba and Nuphar lutea seedlings is completely dependent on DIC. This also applies to Nymphoides peltata seedlings, but for a significantly shorter period. Nymphoides peltata has no morphologically-distinct leaves similar to the underwater leaves of Nuphar lutea and Nymphaea alba. The leaves of Nymphoides peltata produced beneath 
the water surface, however, are very thin and fragile (cf. Glück, 1924). The poor aeration of the aerenchyma of amphibious and aquatic plants during the submerged phase results in ethylene accumulation (Ridge, 1987). The petioles react to ethylene with a strong cell-wall extension (in young petioles and laminae also by an increased cell division; Funke and Bartels, 1937; Malone and Ridge, 1983; Ridge and Amarasinghe, 1984). This elongation leads to a rapid growth of the laminae to the water surface. Once the floating leaves are established, as is the case very soon after germination, the photosynthesis of the young Nymphoides peltata plant becomes independent of DIC.

There are several methods for measuring inorganic $\mathrm{C}$ uptake by aquatic macro- and microphytes. In this study the $\mathrm{pH}$-drift technique introduced by Allen and Spence (1981) was used, involving continuous registration of $\mathrm{pH}$ in a closed system at constant alkalinity. There is good agreement between the results obtained with this potentiometric technique (indirect determination of $\mathrm{C}$ uptake) and those obtained with the Infra-Red Gas Analysator (IRGA) and ${ }^{14} \mathrm{C}$ method (direct determination of $\mathrm{C}$ uptake; Hofslagare et al., 1985). The main drawbacks of the $\mathrm{pH}$-drift technique are: (1) the long incubation time which is often needed to determine the final pH (cf. also Sand-Jensen, 1987); (2) the accumulation of oxygen, which causes an increase in the $\mathrm{CO}_{2}$ compensation points. However, Maberly and Spence (1983) argued that high $\mathrm{O}_{2}$ concentrations are likely to occur in productive aquatic ecosystems, and thus $\mathrm{C}$-extracting capacities estimated at elevated $\mathrm{O}_{2}$ concentrations are ecologically significant.

The floating leaves of Nuphar lutea, Nymphaea alba and Nymphoides peltata show comparable $\mathrm{HCO}_{3}^{-}$-uptake capacities in an 1- $\mathrm{mM} \mathrm{NaHCO}_{3}$ solution. Among other aquatic macrophytes, Maberly and Spence (1983) also determined the C-extracting ability of the floating leaves of Nuphar lutea, albeit under slightly different experimental conditions. However, there is good agreement with the results presented here. In a $1-\mathrm{mM} \mathrm{KHCO}_{3}$ solution they measured a $\mathrm{C}_{\mathrm{T}} /$ Alk ratio for Nuphar lutea of 0.98 (cf. the $\mathrm{C}_{\mathrm{T}} /$ Alk ratio of 0.99 found in this study).

Francko (1986) studied the C-assimilation of Nelumbo lutea (Willd.) Pers. at alkaline and acidic conditions. At $\mathrm{pH} 8.2$ the assimilation rate of ${ }^{14} \mathrm{C}$ exceeded the regeneration rate of $\mathrm{CO}_{2}$ from the aqueous carbonate equilibria. Hence, the observed incorporation of ${ }^{14} \mathrm{C}$ could not account for $\mathrm{CO}_{2}$ uptake alone. He suggested that this relatively high assimilation rate at high $\mathrm{pH}$ was the result of a limited $\mathrm{HCO}_{3}^{-}$uptake.

Maberly and Spence (1983) demonstrated that Elodea canadensis Michx. was unable to use $\mathrm{HCO}_{3}^{-}$at $0.5-\mathrm{mM}$ bicarbonate. When this species was tested in a $1-\mathrm{mM} \mathrm{KHCO}_{3}$ solution, however, a $\mathrm{C}_{\mathrm{T}} / \mathrm{Alk}$ ratio of 0.7 was measured. Such a concentration-dependent uptake of $\mathrm{HCO}_{3}^{-}$was not found for Nymphaea alba, Nuphar lutea and Nymphoides peltata seedlings which had been cultivated for at least 3 weeks at varying alkalinities (Table 4). Indeed, the $C_{T} /$ Alk ratios 
obtained for these macrophytes were lower at higher bicarbonate concentrations, although they did not show values below 0.96 (see Table 4).

There is no sharp dividing line between $\mathrm{CO}_{2}$ - and $\mathrm{HCO}_{3}^{-}$-using macrophytes. It is more appropriate to rank the species in a progressive series for bicarbonate-uptake capacity (Maberly and Spence, 1983). Comparing the $\mathrm{HCO}_{3}^{-}$-uptake capacities of Nymphaea alba, Nuphar lutea and Nymphoides peltata seedlings with those of other macrophytes (Spence and Maberly, 1985), it is evident that these juvenile nymphaeid macrophytes belong to the group of aquatic plants which primarily use dissolved (or atmospheric) $\mathrm{CO}_{2}$ for photosynthesis.

The seedlings of Nymphoides peltata, but especially those of Nymphaea alba and Nuphar lutea, frequently occur in slowly moving or stagnant waters on organic sediments enriched with $\mathrm{CO}_{2}$ (A.J.M. Smits and P. van Avesaath, unpublished data, 1988). It is not known whether these seedlings are able to transport $\mathrm{CO}_{2}$ from the sediment via the roots to the laminae, where it can be used for photosynthesis. In these water bodies, however, the $\mathrm{CO}_{2}$ concentration in the water layer just above the sediment exceeds equilibrium values, so that either way ambient DIC is characterized by a relatively low $\mathrm{HCO}_{3}^{-} / \mathrm{CO}_{2}$ ratio. Assuming that regulation of bicarbonate uptake by the $\mathrm{HCO}_{3}^{-} / \mathrm{CO}_{2}$ ratio (Sand-Jensen and Gordon, 1986) is uniform for all aquatic macrophytes, $\mathrm{HCO}_{3}^{-}$as an alternative inorganic carbon source for Nymphaea alba, Nuphar lutea and Nymphoides peltata seedlings under natural conditions should be of little importance. The high frequency of occurrence of Nuphar lutea and Nymphoides peltata in alkaline waters is probably based on factors which are related to high alkalinity $\left(\mathrm{Ca}^{2+}, \mathrm{Mg}^{2+}\right.$ or other nutrients such as $\mathrm{N}$ or $\mathrm{P}$; van der Velde et al., 1986; de Lyon and Roelofs, 1986). To what extent these parameters influence the occurrence of these nymphaeid macrophytes needs to be investigated.

\section{ACKNOWLEDGEMENTS}

We thank Prof. Dr. C. den Hartog, Dr. C.J.F. ter Braak and Mr. L.A.C.J. Voesenek for critically reading the manuscript. We are much indebted to Dr. C.J.F. ter Braak who kindly advised us on statistics (see Appendix). The Department of Illustration, Faculty of Mathematics and Natural Sciences of the Catholic University prepared the drawings.

\section{APPENDIX}

BY C.J.F. TER BRAAK

Variance and confidence interval for maximum probability in the Gaussianlogit model. 
Using the notation of ter Braak and Looman (1986), the estimated optimum and maximum probability are, respectively,

$u=-b_{1} /\left(2 b_{2}\right)$ and $p_{\max }=1 /\left\{1+\exp \left(-c_{\max }\right)\right\}$

where

$c_{\max }=b_{0}+b_{1} u+b_{2} u^{2}=b_{0}-b_{1}^{2} /\left(4 b_{2}\right)$

using Taylor expansion, we obtain

$\operatorname{var}\left(c_{\max }\right) \approx v_{00}+2 u v_{01}+2 u^{2} v_{02}+u^{2} v_{11}+2 u^{3} v_{12}+u^{4} v_{22}$

where

$v_{k l}$ is the estimated (co)variance between $b_{k}$ and $b_{l}$

$(k=0,1,2 ; l=0,1,2)$

and

$\operatorname{var}\left(p_{\max }\right) \approx p_{\max }^{4} \exp \left(-2 c_{\max }\right) \operatorname{var}\left(c_{\max }\right)$

An approximate $100(1-\alpha) \%$ confidence interval for $p_{\max }$ can be derived from the corresponding interval for $c_{\max }$ by inversion of the logit transformation. The upper and lower limits of the interval for $p_{\max }$ are, respectively,

$p_{u}=1 /\left\{1+\exp \left(-c_{u}\right)\right\}$ and $p_{l}=1 /\left\{1-\exp \left(-c_{l}\right)\right\}$

where

$c_{u}, c_{l}=c_{\max } \pm t \alpha \sqrt{\operatorname{var}\left(c_{\max }\right)}$ with $t \alpha$ the critical value of the two-sided $t$-test at the chosen probability level $\alpha$.

\section{REFERENCES}

Adams, M.S., Guilizzoni, P. and Adams, S., 1978. Relationship of dissolved inorganic carbon to macrophyte photosynthesis in some Italian lakes. Limnol. Oceanogr., 23: 912-919.

Allen, E.D. and Spence, D.H.N., 1981. The differential ability of aquatic plants to utilize the inorganic carbon supply in fresh waters. New Phytol., 87: 269-283.

Arts, G.H.P., 1987. Geschiedenis van de verzuring van zwak gebufferde wateren in Nederland onder invloed van atmosferische depositie. Report 28-01 Dutch Priority Programme on Acidification. Laboratory of Aquatic Ecology, Catholic University of Nijmegen, The Netherlands, $51 \mathrm{pp}$.

Austin, M.P., 1980. Searching for a model for use in vegetation analysis. Vegetatio, 42: 11-21.

Austin, M.P., Cunningham, R.B. and Fleming, P.M., 1984. New approaches to direct gradient analysis using environmental scalars and statistical curve-fitting procedures. Vegetatio, 55: 1127.

Bain, J.T. and Proctor, M.C.F., 1980. The requirement of aquatic bryophytes for free $\mathrm{CO}_{2}$ as an inorganic carbon source: some experimental evidence. New Phytol., 86: 393-400.

Barko, J.W. and Smart, R.M., 1980. Mobilization of sediment phosphorus by submersed freshwater macrophytes. Freshwater Biol., 10: 229-238. 
Barko, J.W. and Smart, R.M., 1983. Effects of organic matter additions to sediment on the growth of aquatic plants. J. Ecol., 71 161-175.

Dacey, J.W.H., 1980. Internal winds in waterlilies: an adaptation for life in anaerobic sediments. Science, 210: 1017-1019.

Dacey, J.W.H., 1981. Pressurized ventilation in the yellow waterlily. Ecology, 62: 1137-1147.

Dacey, J.W.H. and Klug, M.L., 1982. Tracer studies of gas circulation in Nuphar; ${ }^{18} \mathrm{O}_{2}$ and ${ }^{14} \mathrm{CO}_{2}$ transport. Physiol. Plant., 56: 361-366.

De Lyon, M.J.H. and Roelofs, J.G.M., 1986. Waterplanten in relatie tot waterkwaliteit en bodemgesteldheid. Deel 1 and 2. Laboratory of Aquatic Ecology, Catholic University of Nijmegen, The Netherlands, 105 pp., 125 pp.

Drew, E.A. and Robertson, W.A.A., 1974. A simple field version of the Winkler determination of dissolved oxygen. New Phytol., 73: 793-796.

Ellenberg, H., 1983. Vegetation Mitteleuropas mit den Alpen in ökologischer Sicht. 3rd edn. Ulmer Verlag, Stuttgart, $989 \mathrm{pp}$.

Filbin, G.J., 1980. Photosynthesis, photorespiration and primary productivity in floating leaved and emergent plants. Thesis, Wayne State University, Detroit, MI, 252 pp.

Francko, D.A., 1986. Studies on Nelumbo lutea (Willd.) Pers. II. Effects of $\mathrm{pH}$ on photosynthetic carbon assimilation. Aquat. Bot., 26: 119-127.

Funke, G.L. and Bartels, P.M., 1937. Observations on the growth of water plants. Biol Jaarb. Dodonaea, 4: 316-344.

Glück, H., 1924. Biologische und Morphologische Untersuchungen über Wasser- und Sumpfgewächse IV. Untergetauchte und Schwimmblattflora. Gustav Fischer, Jena, 746 pp.

Grosse, W.and Mevi-Schütz, J., 1987. A beneficical gas transport system in Nymphoides peltata. Am. J. Bot., 74: 947-952.

Hellquist, C.B., 1980. Correlation of alkalinity and the distribution of Potamogeton in New England. Rhodora, 82: 331-344

Heslop-Harrison, Y., 1955a. Nuphar Sm. Biological flora of the British Isles. J. Ecol., 43: 342364.

Heslop-Harrison, Y., 1955b. Nymphaea L. em. Sm. (nom. conserv.). Biological flora of the British Isles. J. Ecol., 43: 719-734.

Hofslagare, O., Samuelsson, G., Hällgren, J.E., Pejryd, C. and Sjöberg, S., 1985. A comparison between three methods of measuring photosynthetic uptake of inorganic carbon in algae. Photosynthetica, 19: 578-585.

Hutchinson, G.E., 1975. A Treatise on Limnology. Vol. 3. Limnological Botany. Wiley, New York, NY, $660 \mathrm{pp}$.

Iversen, J., 1929. Studien über die pH-Verhältnisse dänischer Gewässer und ihren Einfluss auf die Hydrophyten-Vegetation. Bot. Tidsskr., 40: 277-333.

Kadono, Y., 1982a. Distribution and habitat of Japanese Potamogeton. Bot. Mag., 95: 63-76.

Kadono, Y., 1982b. Occurrence of aquatic macrophytes in relation to $\mathrm{pH}$, alkalinity, $\mathrm{Ca}^{2+}, \mathrm{Cl}^{-}$ and conductivity. Jpn. J. Ecol., 32: 39-44.

Maberly, S.C. and Spence, D.H.N., 1983. Photosynthetic inorganic carbon use by freshwater plants. J. Ecol., 71: 705-724.

Malone, M. and Ridge, I., 1983. Ethylene-induced growth and proton excretion in the aquatic plant Nymphoides peltata. Planta, 157: 71-73.

Merget, A., 1874. Sur la réproduction artificielle des phénomènes de thermo-diffusion gazeuse des feuilles, pars les corpes poreaux et pulverulents humides. C. R. Acad. Sci. 78: 884-886.

Ohno, N., 1910. Über lebhafte Gasausscheidung aus den Blättern von Nelumbo nucifera Gaertn. Z. Pflanzenphysiol., 2: 641-664.

Peñuelas, J., 1985. $\mathrm{HCO}_{3}^{-}$as an exogenous carbon source for aquatic byrophytes Fontinalis antipyretica and Fissidens grandifrons. J. Exp. Bot., 36: 441-448. 
Pietsch, W., 1972. Ausgewählte Beispiele für Indikatoreigenschaften höherer Wasserpflanzen. Arch. Naturschutz Landschaftsforsch., 12: 121-151.

Pip, E., 1979. Survey of the ecology of submerged aquatic macrophytes in central Canada. Aquat. Bot., 7: 339-357.

Raven, J.A., 1970. Exogenous inorganic carbon sources in plant photosynthesis. Biol. Rev., 45: 167-221.

Ridge, I., 1987. Ethylene and growth control in amphibious plants. In: R.M.M. Crawford (Editor), Plant Life in Aquatic and Amphibious Habitats. Special Publication No. 5 Br. Ecol. Soc., Blackwell Scientific Publications, Oxford, pp. 53-76.

Ridge, I. and Amarasinghe, I., 1984. Ethylene and growth control in the fringed waterlily (Nymphoides peltata): stimulation of cell division and interaction with buoyant tension in petioles. Plant Growth Reg., 2: 235-249.

Sand-Jensen, K., 1987. Environmental control of bicarbonate use among freshwater and marine macrophytes. In: R.M.M. Crawford (Editor), Plant Life in Aquatic and Amphibious Habitats. Special Publication No. 5 Br. Ecol. Soc., Blackwell Scientific Publications, Oxford, pp. 99112.

Sand-Jensen, K. and Gordon, D.M., 1986. Variable $\mathrm{HCO}_{3}^{-}$affinity of Elodea canadensis Michaux in response to different $\mathrm{HCO}_{3}^{-}$and $\mathrm{CO}_{2}$ concentration during growth. Oecologia, 70: 426-432.

S.A.S., 1986. S.U.G.I. Supplemental Library User's Guide. 5th edn. S.A.S. Institute Inc., Cary, NC, pp. 662.

Sculthorpe, C.D., 1967. The Biology of Aquatic Vascular Plants. Edward Arnold, London, 610 pp.

Spence, D.H.N., 1967. Factors controlling the distribution of freshwater macrophytes with particular reference to the lochs of Scotland. J. Ecol., 55: 147-170.

Spence, D.H.N. and Maberly, S.C., 1985. Occurrence and ecological importance of $\mathrm{HCO}_{3}^{-}$use among aquatic higher plants. In: W.J. Lucas and J.A. Berry (Editors), Inorganic Carbon Uptake by Aquatic Photosynthetic Organisms. Waverly Press, Baltimore, MD, $494 \mathrm{pp}$.

Steemann-Nielsen, E., 1944. Dependence of freshwater plants on quantity of carbon dioxide and hydrogen ion concentration. Dansk Bot. Ark., 11: 1-25.

Stumm, W.A. and Morgan, J.J., 1981. Aquatic Chemistry. Wiley, New York, NY, 780 pp.

Ter Braak, C.J.F. and Looman, C.W.N., 1986. Weighted averaging, logistic regression and the Gaussian response model. Vegetatio, 65: 3-11.

Van der Velde, G., Custers, C.P.C. and De Lyon, M.J.H., 1986. The distribution of four nymphaeid species in The Netherlands in relation to selected abiotic factors. Proc.EWRS/AAB 7th Symp. on Aquatic Weeds, Loughborough 1986, pp. 363-368.

Weaver, C.I. and Wetzel, R.G., 1980. Carbonic anhydrase levels and internal lacunar $\mathrm{CO}_{2}$ concentrations in aquatic macrophytes. Aquat. Bot., 8: 173-186.

Wiegleb, G., 1978. Untersuchungen über den Zusammenhang zwischen hydrochemischen Umweltfaktoren und Makrophytenvegetation in stehenden Gewässern. Arch. Hydrobiol., 83: 443484 . 